\title{
Two Greek Ostraca from Jeme in Cambridge
}

\author{
Nikolaos Gonis*
}

\begin{abstract}
Full publication of O.Camb. 114 and 115.
Keywords: diagraphon, dianome, requisitions, cushions, strategos

DOI 10.1515/apf-2016-0032

The ostraca edited in this article were first published in the form of short descriptions by J.G. Tait in Greek Ostraca in the Bodleian Library at Oxford and Various Other Collections I (1930), part IV, 'Ostraca in the Cambridge University Library', p. 170. Inspection of the originals showed them to be more legible than reported and not without interest. ${ }^{1}$ Internal evidence indicates that they both come from Jeme, and thus they join the small number of texts from this area written entirely in Greek.
\end{abstract}

\section{Receipt for diagraphon}

O.Camb. 115

$$
6.1(\mathrm{w}) \times 5.5(\mathrm{~h}) \mathrm{cm}
$$

24 July $c .730$

Described as a 'Tax-receipt, 5 lines, illegible', this text concerns a payment of $1 / 3$ solidus for $\mu \varepsilon^{\prime} \rho \varsigma_{\zeta} \delta 1 \alpha \gamma \rho \alpha ́ \varphi o v$, due for indiction 11 (727/8). The

Vorbemerkung: I am grateful to Lajos Berkes for comments on a draft. The images are reproduced courtesy of the Digital Content Unit, Cambridge University Library (for help with this, I thank Dr Suzanne Paul, Keeper of Manuscripts and University Archives at the CUL).

* Kontakt: Nikolaos Gonis, Department of Greek and Latin, University College London, London WC1E6BT, <n.gonis@ucl.ac.uk>

${ }^{1}$ As a decipherer of ostraca of the Ptolemaic and Roman periods, Tait has had no equal, but he had little interest in texts of the later periods ('Byz[antine] pap[yri] are no good to Tait', wrote A.S. Hunt to H.I. Bell on 12 April 1924). 
date is partly obscured by a scratch on the surface, which has rendered the indiction number illegible, but comparison with other receipts in this format suggests that it was issued in indiction 13 (729/30). One of the signatories is a new strategos. The other may be identified with a person who signed numerous tax receipts in Jeme in 727-8 (see below, $5 \mathrm{n}$.).

The end of the text is lost; one or two further signatures, including that of the scribe, will have followed.
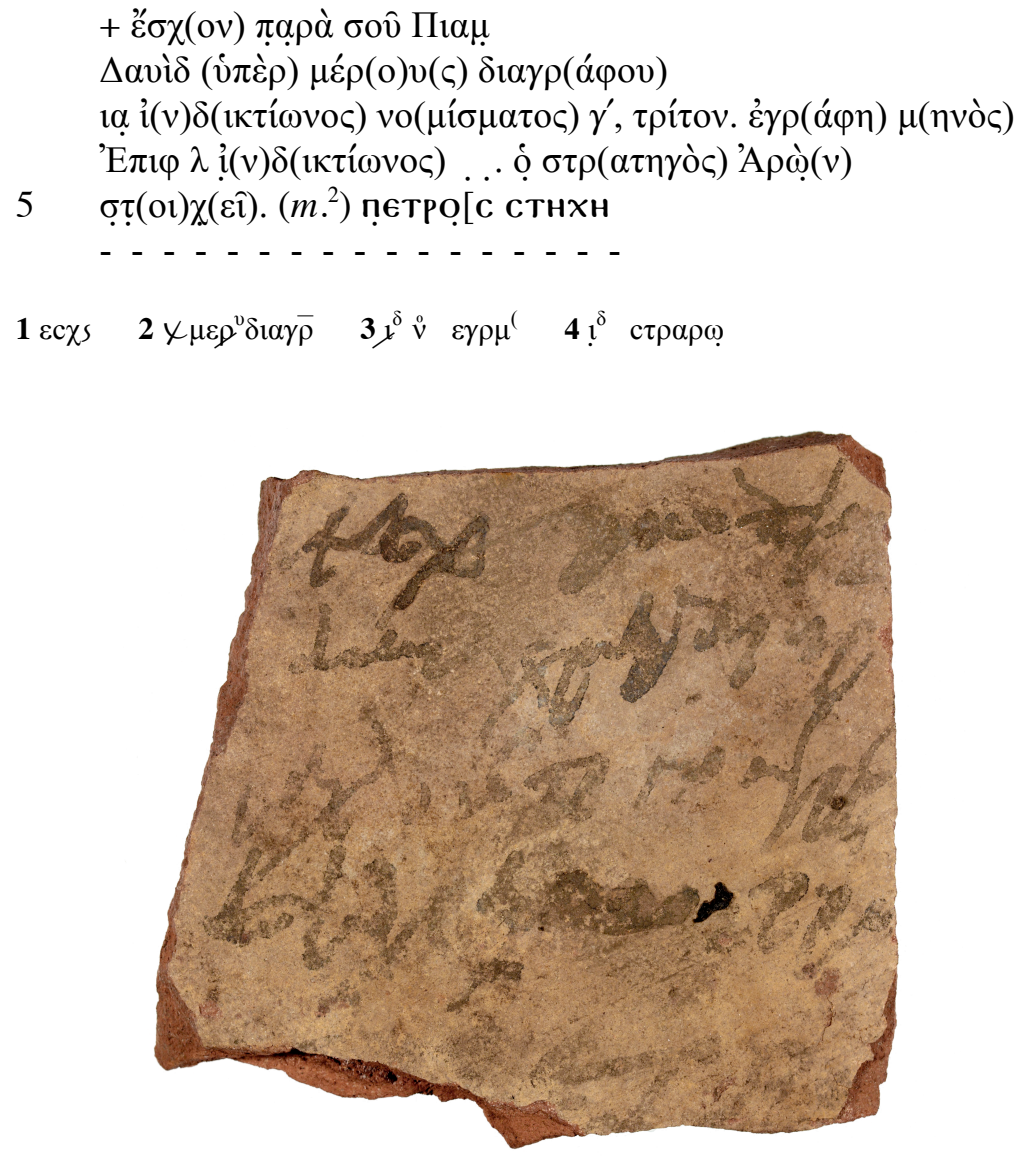

'I received from you, Piam son of David, for part of the diagraphon of the $11^{\text {th }}$ indiction, sol. $1 / 3$, one-third. Written in the month of Epiph 30, indiction (13?). The strategos Aron agrees.' ( $2^{\text {nd }}$ hand) 'Petros agrees ...' 


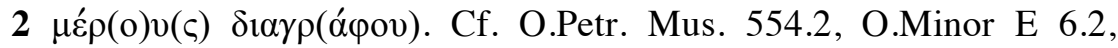
O.Alex. inv. 19940.3 (ed. K.A. Worp, BSAC 42 [2003] 99-102).

4 ọ $\sigma \tau \rho(\alpha \tau \eta \gamma \hat{o} \varsigma)$ 'A $\rho \omega \varphi(v)$. I owe the reading of the name to a suggestion of L. Berkes. There are no other attestations of this strategos, but we know of an ape of Jeme called Aron, and the terms ape and strategos are thought to be synonymous (see P.Strasb. Copt., p. 224f.); there is also a lashane of this name. See W.C. Till, Datierung und Prosopographie der koptischen Rechtsurkunden aus Theben (1962) 63.

In most receipts from this area, especially Coptic, which were signed by strategoi, the function follows the name of the official. It precedes it in a few other Greek receipts: O.Camb. 114.4 (see below), O.Heid. 448.4, 449.5, O.Minor E 6.4 (with BL VIII 536), and the account O.Petr. Mus. 595.1 , where read $\sigma \tau \rho(\alpha \tau \eta \gamma$ ó $\varsigma)$ instead of $\pi \rho(\varepsilon \sigma \beta\langle ́ \tau \varepsilon \rho \circ \varsigma)$ (originally transcribed as $\tau \rho /$ in O.Petr. 447).

5 nє Petros who appears as a signatory in tax receipts written by Aristophanes son of Ioannes in 727-8, always paired with Andreas; for a (partial) list of occurrences, see Till, Datierung und Prosopographie 174. The misspelled СтнХн is restored after these other instances.

\section{Receipt for dianome}

O.Camb. 114

$9(\mathrm{w}) \times 8(\mathrm{~h}) \mathrm{cm}$

28 February 732

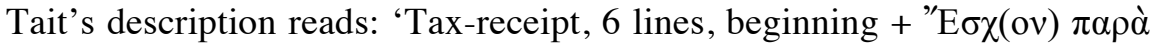

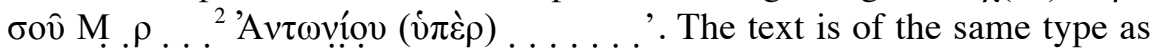
O.IFAO inv. 146, ed. J. Gascou in Mélanges Cécile Morrison (T\&MByz 16 [2010]) 384-5, which is in a bad state of preservation and whose text can be improved in the light of its Cambridge sister-piece. Both receipts concern the same tax and are signed by the same persons, two of whom recur in O.Heid. 448 and 449, both dated Mesore 8, indiction 1 (1 August 732). These are the only two known receipts of this period issued for the supply of items (in this case, a cushion), no doubt in the context of a requisition.

The tax-payer in the IFAO ostracon has been identified with a known person from Jeme, but even without this indication, Jeme would have been the most likely place of origin. 


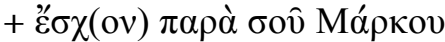

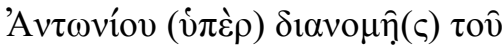

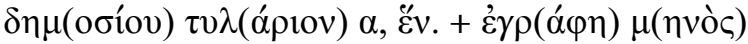

$\Phi \alpha \mu(\varepsilon v \omega) \theta \gamma \dot{i}(v) \delta(1 \kappa \tau i ́(\omega v o \varsigma) 1 \varepsilon .+\dot{o} \sigma \tau \rho(\alpha \tau \eta \gamma o ̀ \varsigma) K \hat{v} \rho ı$

$5 \sigma \tau \mathrm{\sigma} \chi(\varepsilon \hat{\imath}) .\left(m .{ }^{2}\right) \operatorname{Kvpl\alpha \kappa }(\grave{\mathrm{o}} \varsigma) \sigma \tau(\mathrm{o \imath}) \chi(\varepsilon \hat{\imath})$. (vac.)

(m.1) $\Delta \alpha v i \delta$ है $\gamma \rho(\alpha \psi \alpha)$.

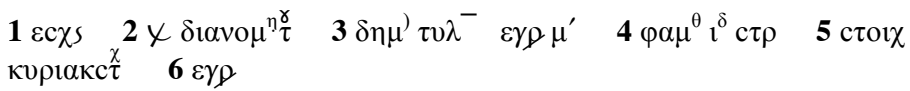

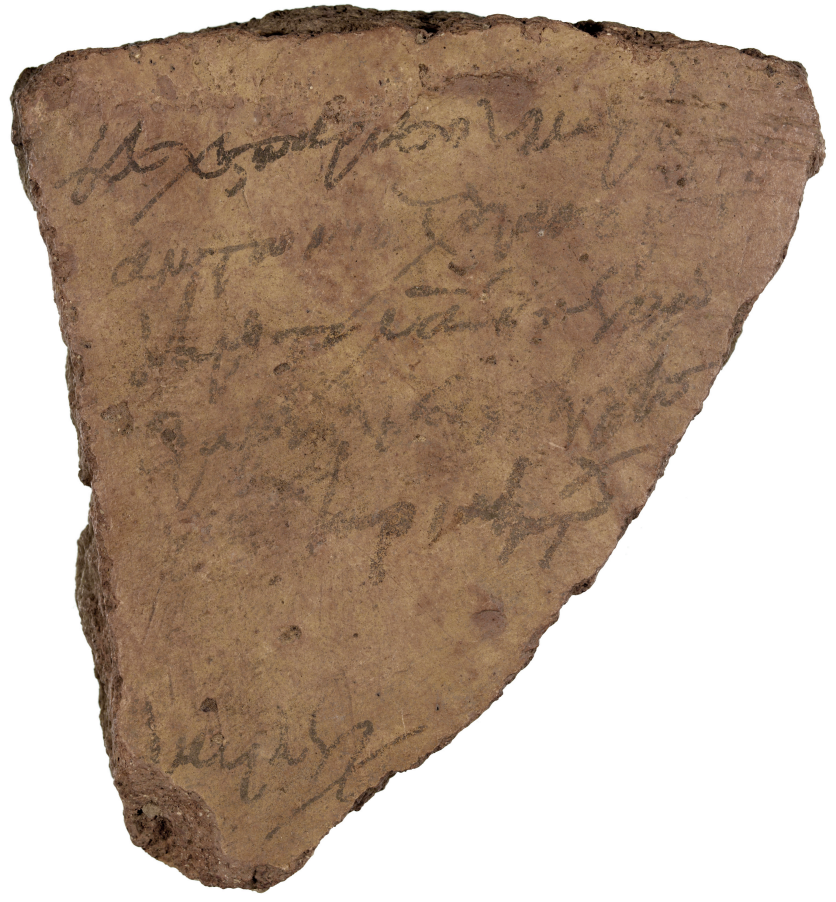

'I received from you, Markos son of Antonios, for the dianome of the public (treasury), 1, one, cushion. Written on the $3^{\text {rd }}$ of the month of Phamenoth, indiction 15 . The strategos Kyris agrees.' ( $2^{\text {nd }}$ hand) 'Kyriakos agrees.' ( $1^{\text {st }}$ hand) 'I, David, wrote.' 


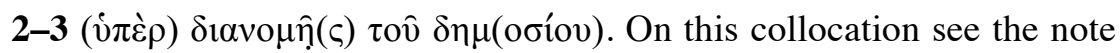
to O.IFAO inv. 146.2. On the term $\delta 1 \alpha v o \mu n$ in general, see F. Mitthof, SPP $\mathrm{III}^{2} .2$ pp. xxiii-xxiv.

$3 \tau v \lambda(\alpha ́ \rho 10 v)$. $\tau v \lambda \alpha \rho^{\prime} 1 \alpha$ occur in the context of requisitions for the fleet, and refer to cushions used by sailors; see F. Morelli, CPR XXII $48.7 \mathrm{n}$. In O.IFAO inv. $146.2 \operatorname{read} \tau v \lambda(\alpha ́ \rho ı v) \alpha$ instead of $\alpha \hat{\alpha} \rho(i \theta \mu ı v)(v o ́ \mu \imath \sigma \mu \alpha$ ?) $\alpha$.

4-6 O.IFAO inv. 146.4-6 should now be presented as follows:

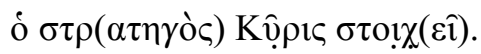

Kụ̣ı $\alpha$ K(ò $\varsigma) \sigma \tau(\mathrm{o \imath}) \chi(\varepsilon \hat{\imath})$.

$\Delta \alpha v i \delta$ '̌ $\gamma \rho(\alpha \psi \alpha)$.

$4 \Phi \alpha \mu(\varepsilon v \omega) \theta \gamma$. O.IFAO inv. 146 also dates from Phamenoth, but the month-day and indiction figure are not legible.

ó $\sigma \tau \rho(\alpha \tau \eta \gamma \grave{c} \varsigma)$ Kộpıc. This official is not known from any other text except for these two ostraca. For the construction see above, $14 \mathrm{n}$.

5 Kvpıк(óc). The same signatory (same hand) occurs in O.Alex. inv. 19940.7, O.Heid. 448.6, and 449.6.

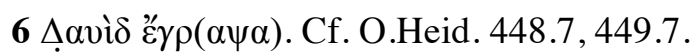

